\title{
A Better Intellectual Community Is Possible: Dialogues with Ali A. Mazrui
}

James H. Mittelman

\begin{abstract}
To probe the changing roles and responsibilities of intellectuals, this article explores the world of Ali Mazrui, one of Africa's best-known scholars. Mazrui's lifelong work spans the entire postcolonial period, and offers a prism for viewing African studies. Methodologically, this intellectual ethnography stages dialogues between Mazrui and other leading thinkers who have examined the nexus of knowledge and power. More specifically, Mazrui engages in controversies on complex issues such as Afrocentrism, religiosity, gender, and youth. Debates with his critics address fundamental questions facing Africa: grappling with social transformation, expanding policy space, and building ladders of development.
\end{abstract}

Résumé: Afin d'enquêter sur l'évolution des rôles et des responsabilités des intellectuels, cet article explore le monde de Ali Mazrui, un des théoriciens les plus connus de l'Afrique. Les écrits de Mazrui s'étendent sur l'ensemble de la période postcoloniale, et offrent un prisme d'observation sur les études africaines. Sur le plan méthodologique, cette ethnographie intellectuelle met en scène des dialogues

African Studies Review, Volume 57, Number 1 (April 2014), pp. 153-170

James H. Mittelman is University Professor of International Affairs at American University. He served as dean and professor at the Graduate School of International Studies (now the Korbel School), University of Denver, and dean and professor at Queens College of the City University of New York. He has also held teaching and research appointments in Japan, Malaysia, Mozambique, South Africa, and Uganda. The recipient of the International Studies Association's International Political Economy Distinguished Senior Scholar Award in 2010, Mittelman was a member of the Institute for Advanced Study in Princeton and is an honorary fellow at the Helsinki Collegium for Advanced Studies. His books include Ideology and Politics in Uganda: From Obote to Amin (Cornell University Press, 1975), The Globalization Syndrome: Transformation and Resistance (Princeton University Press, 2000), and Hyperconflict: Globalization and Insecurity (Stanford University Press, 2010). E-mail:jmittel@american.edu 
entre Mazrui et d'autres grands penseurs qui ont examiné le lien entre la connaissance et le pouvoir. Plus précisément, Mazrui s'engage dans des controverses sur des questions complexes telles que l'afro-centrisme, la religiosité, le sexe, et la jeunesse. Les débats avec ses critiques évoquent des questions fondamentales qui concernent l'Afrique: la gestion de la transformation sociale, l'élargissement de l'espace politique, et la construction des étapes du développement.

Key Words: Identity; intellectual; Pan-Africanism; postcolonial theory

In our arduous times, what are the changing roles of intellectuals? What are their responsibilities to society? To examine these issues in the African context, let us peer into the world of Ali Mazrui, one of the continent's bestknown scholars. He has had great influence on the public, political authorities, and generations of youth to whom civilizational values are transmitted. This process is how societies perpetuate themselves and adapt to changing conditions. At issue are social reproduction and the analytical foundations of democratic deliberations, or, conversely, repressive tendencies. These legacies shape the common heritage of a society and safeguard the expressive freedom of its institutions. The stakes in the nexus of knowledge and power are therefore quite high, as evident in the case of Mazrui's lifelong work.

The approach in this article is intellectual ethnography. It examines one scholar's transcripts, his creativity, his use of analogy, and the power of storytelling. The discussion that follows is meant to offer a prism, albeit a partial one, for viewing African studies.

In probing Mazrui's conceptual makeup, let us not confuse substance and style. I salute his substance, applaud his panache, and will issue critical challenges. I will proceed with respect and admiration, but know that Mazrui would give me a failing mark if I were to shirk my academic responsibility and try to worm out of scholarly debate, which, after all, is our stock-in-trade, our métier.

The exchange here is staged as a series of imaginary interlocutions with four theorists who have addressed the roles of intellectuals in society: Antonio Gramsci, Max Weber, Edward Said, and Thandika Mkandawire. This platform will give Mazrui, an artisan skilled in repartee, an opportunity to ply his craft. He thrives on criticism; it elicits the best in him as he envisages a better intellectual community.

One caveat: if I have overlooked a crucial reading for this assignment, I plead guilty on the ground that Mazrui's output is massive; the sheer quantity would practically fill a library. And his creative energies are exceptional. Having read or reread several Mazrui scripts, I have sought to do my homework, and hope that the professor will tread gingerly on any errors of omission, though not commission.

For the sake of full disclosure, I should reveal that Ali and I first met in 1967 when I enrolled in the M.A. program in African Studies at Makerere 
University: at the time, a part of the University of East Africa, a regional institution with campuses in Uganda, Kenya, and Tanzania. Then, as now, he boosted many young academics. I should know. As head of the Department of Political Science and Public Administration, and dean of the Faculty of Social Sciences, Ali created the position of special tutor, enabling me to return to Uganda in 1970. I have never recovered from this good fortune. Ever since our Makerere days, Ali has been an esteemed colleague, and we have enjoyed many fruitful exchanges.

While I have benefited from Ali's bigheartedness, he would not want those good deeds to impinge on an honest dialogue. Ali's generous spirit certainly did not prevent him from exercising his administrative duties at Makerere, as when he understandably grew cross with me. Rightly, Ali reproached me for my absences from Kampala on account of straying to Karamojo in the northern reaches of Uganda, archaeological digs at the ancient kingdom of Bunyoro-Kitara, Rwandan refugee camps in the south, and neighboring countries. Noting my peripatetic ways, he remarked that I must have Somali genes. Likened to a pastoralist, I perhaps should have been quick on my feet and tossed a Mazrui-like turn of phrase back at him: if I am given to geographical wanderlust, you, Ali, are prone to intellectual wanderlust. This trait is the result of his inquiring mind that dares dart from one theme to another without hesitating to hurl spears of argumentation at others on a journey of knowledge generation. Truly, Mazrui's vocation is intellectual curiosity fueled by strong convictions.

\section{The Intellectual Calling}

By definition, intellectuals are fascinated with ideas. Our calling is the passion to battle over the production of new knowledge. That said, there are myriad valuable reflections on the lot of the intelligentsia. Although some formulations transcend context, world regions have conceived their own positions on this issue. Whereas the genesis of the knowledge structure in the West differs from that in Africa, there is no need to proceed de novo. We can draw on eminent analysts as markers for gauging the roles of intellectuals in respect to social transformation.

To structure the ensuing discussion, it is well to highlight telling points

made by Gramsci, Weber, Said, and Mkandawire. ${ }^{1}$ Before tracing the ideas of these four authors, however, a few words are needed about why I selected them as touchstones for weighing Mazrui's work. Of necessity a long list of writers would be impossible to fit into this article. But the heuristic of imagined dialogues with this particular set of theorists evokes insights about knowledge production larger than engagement with sundry individuals' contributions. This assemblage is derived from times of social disruption in the thinkers' respective contexts: for Gramsci, the stormy period of Italian fascism; for Weber, societal conflicts linked to Germany's transition to a world industrial power; for Said, struggles over Palestinian statehood; and for Mkandawire, opposition to strongman rule in Africa. For Mazrui, the 
climate was that of decolonization, followed by political turbulence and punctuated by military interventions. Moreover, these other four savants, together, represent Mazrui's intellectual heritage: Western, Middle Eastern, and African. Drawing on their legacies, they trained their lenses on not only the intelligentsia but also cultural values, practices, and policies, as does Mazrui. Collectively, the interrogators provide a framing device for discovering nuance in Mazrui's scholarship. Let us now turn to their contentions.

These astute observers alike were quick to recognize different types of intellectuals. Especially important is Gramsci's (1971) distinction between traditional and organic intellectuals. Be they teachers, ecclesiastics, or bureaucrats, traditional intellectuals present themselves as autonomous and independent of other social groups. In Gramsci's telling, this attempt to claim the mantle of a specialized function and unitary character is a utopian quest, for intellectuals are a part of the complex of social relations. Inasmuch as traditional intellectuals were connected to slavery in the classical world and with the dominant order in China's empires, they are in no way detached from social and racial separations but hold on to the privileges that derive from being a segment of a strong group. By contrast, organic intellectuals are another stratum, also associated with a class. They help to organize interests, articulate goals, seek to legitimize them, and elicit consent. Usually, organic intellectuals are linked to an ascendant class or movement. It is important not only to grasp the position of intellectuals in a given social structure (i.e., with regard to class, race, ethnicity, gender, and religious groups) but also in their relationship to power.

Coming from another theoretical and political angle, Weber (1973[1946]:176) maintains that intellectuals are a group that articulates "cultural values" and propagates the "national idea." He distinguished intellectuals from a class of cultured "literati": traditionalists who become an exclusive stratum, seek to maintain the status quo and status privileges, and throttle transformation. Further, Weber held that "an ethic of ultimate ends and an ethic of responsibility are not absolute contrasts but rather supplements, which only in unison constitute a genuine man-a man who can have the "calling for politics" (1973[1946]:127; emphasis in original). In a beautiful passage, he urged diverse intellectuals to articulate the importance of tolerance and respect for all groups, and to build a society with many vibrant cultures: "Only he has the calling for politics who is sure that he shall not crumble when the world from his point of view is too stupid and too base for what he wants to offer. Only he who in the face of all this can say 'In spite of it all!' has the calling for politics" (1973[1946]:128).

Also seeking reconciliation, particularly between Palestinians and Israelis, Said, a Palestinian American political activist who spent his childhood in Jerusalem and Cairo before becoming University Professor of English and Comparative Literature at Columbia University, directly addressed both the Western and postcolonial worlds. In his 1993 Reith Lectures broadcast by the British Broadcasting Corporation (BBC) (Said 1994), Said stressed that the intellectual represents a particular standpoint and is obliged to disturb 
taken-for-granted knowledge. When intellectuals advocate for their beliefs, whether by speaking, writing, mentoring, or making media appearances, they incur grave risks. Moreover, they must draw inspiration from a steely will, and have athlete-like stamina to sustain views that tilt against convention. The point of it all is to unsettle the dominant order and etch alternatives that are often marginalized.

These roles may land the intellectual in exile, as with Said's own station in New York. The exile condition may take the form of displacement to another geographical place or a metaphorical state for outsiders in their country of origin. The intellectual as an exile plays this role not only by virtue of personal background but also by way of destabilizing the extant knowledge-power structure.

\begin{abstract}
Exile is a model for the intellectual who is tempted, and even beset and overwhelmed, by the rewards of accommodation, yea-saying, settling in. Even if one is not an actual immigrant or expatriate, it is still possible to think as one, to think and imagine in spite of barriers, and always to move away from centralizing authorities toward the margins, where you see things that are usually lost on minds that have never traveled beyond the conventional and comfortable. (1994:63)
\end{abstract}

To speak personally, I find Said's contention that the exile condition is not merely a matter of one's passport to be compelling. It may offer solace to scholars dislodged from their "homeland." But what is a "homeland?"2 Line-drawing between being inside and outside of one's "homeland"-the inclusion of friends and the exclusion of strangers-is a process of social construction. After all, how do discourse brokers fashion a keyword such as "homeland security"? And in what manner is the meaning appropriated so as to form categories of outsiders, even within territorial borders? In our age, the U.S. government's wordsmiths have long claimed that it aimed to protect its own (read "homeland") citizens against "terrorist organizations," and, in 1986, placed Nelson Mandela's African National Congress (ANC) on its secret watch list of terrorists. Only in 2008, fifteen years after Mandela won the Nobel Peace Prize, did Washington relent and delist the ANC.

In view of such policies, dissident intellectuals in the United States and elsewhere have sought to rock the power structure. Some of us could easily identify with Said's notion that one can be an exile, an outsider looking in, including in one's country of origin. For me, it is being a critical thinker, an outlier, observing the insiders in Washington, D.C., where a throng of policy intellectuals, among them think tankers, serve as what I seem to recall Said once dubbed "therapists for the state and for power in our societies." In Said's sense, and according to postcolonial theory, for which he was a catalyst, identity formation is a question of Othering, that is, naming "we" and "they" and using this designation for a political project. The point is that fence-building is central to the postcolonial context as well as to the everyday lives of diasporic peoples. 
This intersubjective condition is similarly about standpoint epistemology, which is central to gender analysis: mindfulness of where one is situated in a social and spatial hierarchy. Viewing things both from the lens of what he or she has seen elsewhere and comparing it to a new domicile, the intellectual has the advantage of a double outlook that helps develop universal ideas about human dignity and rights while taking into account contingencyrespect for beginnings and evolving processes on which institutions are built rather than "being awed by the august personality" (Said 1994:61).

Like Said, Mkandawire knows the exile condition and is concerned with knowledge production, especially in higher education at research organizations in postcolonial Africa. A Swedish national who was imprisoned under President Hastings Banda in his home country of Malawi, Mkandawire holds the Chair in African Development at the London School of Economics and Political Science. Putting forth germinal ideas in the CODESRIA Bulletin (Mkandawire 1995; also see Mkandawire 2010), he identified three generations of indigenous researchers in Africa.

Mostly educated overseas, the first generation helped fashion and propagate the state's developmentalist ideology. It established pan-African research networks and institutions like the Council for the Development of Social Science Research in Africa (CODESRIA), which set out to decolonize national organizations and invigorate the intellectual community. Also trained abroad, many members of the second generation returned home but became disenchanted owing to the constraints on intellectual production and joined the brain drain. In Africa, they encountered intractable problems, including limited professional opportunity in university positions taken by the first generation, economic downturn, the decay of African states, and increasing pressures on academic freedom. Hence a wave of academic refugees became economic refugees.

Largely produced locally, indubitably under onerous conditions, the third generation of social scientists is increasingly at the helm of African universities. Early on, they encountered a multitude of experts who brought structural adjustment and technical assistance programs but not durable educational infrastructure, such as adequate libraries and technology. Mkandawire's hope is that this generation will "initiate an autonomous discourse and reflection on Africa-autonomous not in the sense that it is isolated but in the sense that it takes the specificities of the African experience seriously and has a proactive rather than reactive relationship with non-African scholarship" (1995:11). ${ }^{3}$ Now that efforts to rehabilitate African universities and vitalize its research networks are afoot, it will be worthwhile to take this vision into account in what follows on Mazrui's contributions.

\section{A Maverick Course}

How does Mazrui's intellectual legacy measure up on this matrix of emphases: social embeddedness (Gramsci), responsibility (Weber), representations (Said), and autonomous discourses (Mkandawire)? 
It must first be said that Mazrui is a maverick, an iconoclast who does not fit easily into any one slot, be it in the mainstream or currents that cut against it. Admirers and critics have chronicled his decades-long intellectual journey (Kokole 1998; Morewedge 2001). Mazrui's fans have provided eloquent tributes to his prolificacy and versatility. Volumes of his collected essays (among them, Mazrui 2002) themselves are testimony to his tireless efforts to stimulate the exchange of knowledge. If the young Mazrui (e.g., 1967a, 1967c) was steeped in political philosophy and political sociology, Mazrui the elder is more on the sociological and cultural side. In these domains, he exhibits great scope and ability to stir debates among Africanists.

Whereas political thought remains one of his principal concerns, he has veered more toward examining cultural hybridity and capturing the fluidity of flows in Africa (e.g., Mazrui, Dikirr, \& Kafrawi 2008). An intellectual pluralist trekking across disciplinary borders, Mazrui eagerly enters sensitive terrains, including those of gender, religion, race, ethnicity, and identity. He has engaged in controversies over Afrocentrism, religiosity, anti-Semitism, the language question in Africa, neocolonialism, and nuclear proliferation. Mazrui is an intellectual provocateur in an exhilarating way.

Let us now pursue this theme. Setting up global dialogues with other intellectuals will give Mazrui a forum for displaying his skills as an analyst, his penchant for dancing with words, and, I dare say, his sheer pluck.

\section{Gramsci and Mazrui}

From early in the postcolonial period, Mazrui has been a pioneer. For example, his initial foray into the construct "global Africa" was avant-garde in the scholarly literature. He provided an anticipation of research on the ways in which globalization touches down on the continent and the responses to these forces.

Yet imagine an encounter between Gramsci and Mazrui. Gramsci would ask, "Are you a traditional intellectual holding fast to privilege or an organic intellectual linked to a popular class or movement? Whom do you stand for? Which elements in the social and power structure?" A member of the Communist Party who wrote from an Italian prison during the Mussolini years, Gramsci sought to overturn the dominant system of material and political power. Attuned to cultural dynamics, he would query: "Why, Ali Mazrui, do you find an analysis that focuses on meanings and whole ways of life more compelling than studies that link material culture to critical political economy? Do you emphasize the ideational aspects of culture and underemphasize their material dimensions?"

In fact, an influential school in cultural studies and some feminists build on the tradition of cultural materialism pioneered by Marvin Harris (2001 [1968]), who was decisively influenced by his fieldwork in Mozambique. If he were with us today, Gramsci might well say: "True, you do not ignore capitalist power (Mazrui 1990). Yet as you well know, giants in African studies, such as the historian Walter Rodney, the political scientist Claude 
Ake, the poet Dennis Brutus, and the law professor Issa Shivji, have advanced vigorous critiques of capitalism, understood as a mode of production and a system of accumulation, truly an engine of dispossession in Africa. And you, Ali? Please elaborate your position.”

\section{Weber and Mazrui}

In the next imaginary dialogue, Weber would applaud Mazrui's focus on leaders and authority types. His selection of notables includes several heads of state: among others, Idi Amin, Nnamdi Azikiwe, Félix Houphet-Böigny, Ellen Johnson Sirleaf, Gamal Abdel Nasser, Kwame Nkrumah, Julius Nyerere, and Milton Obote. August personalities in literature and the arts plus Nobelists like Wangari Maathai and, also named a laureate in 2011, Johnson Sirleaf, receive attention, too. As highlighted in the title of one of Mazrui's books, On Heroes and Uhuru-Worship (1967b), heroism is a major theme coursing through Mazrui's work.

Akin to Weber's approach, Mazrui's relies on moral reasoning and stresses the responsibility of intellectuals to bring to the fore diverse cultural values. Surely the culturally laden exercise of naming heroes and antiheroes is a way of bracketing the world. Heroism variously involves legitimation of certain values, myth-making, and the identification of individuals and groups as villains. The cultural motif of heroism is played out differently in diverse civilizations. In the Western tradition, as in the mythology of ancient Greece and Rome, classics like Homer's Iliad, and, later, Shakespeare's kings, heroic violence is romanticized. And with the rise of modernity, Karl Marx sought to tie heroism and violence under capitalism: "Unheroic though bourgeois society is, it nevertheless needed heroism, sacrifice, terror, civil war, and national wars to bring it into being" (1852:116, as quoted in Jung 2003:10). Steering clear of this dialectic, Weber (1973[1946]) looked at heroes as superior individuals. For him, heroism is an attribute that leaders strive to attain. It is what enables them to reach the possible, though, time and again, it appeared impossible.

In the African context, Ngũgĩ wa Thiong'o (1986) eloquently underscored that colonialism erased peoples' memories, and told other stories about their history. With decolonization, nationalism invented new heroic narratives. The postcolonial order memorialized and monumentalized its storylines. These are largely tales of male heroism. They associate heroism with masculinity and strength. But the old order cried out at the changes, some of them transmitted through Western educational institutions.

The Ugandan novelist and poet Okot p'Bitek expressed it pointedly. Mindful of the impact of Western paradigms on African education, p'Bitek's character Lawino laments the change in a son of Acholi, her Westernized husband:

Bile burns my inside!

I feel like vomiting!

For all our young men 
Were finished in the forest,

Their manhood was finished

In the class-rooms,

Their testicles

Were smashed

With large books! (1966:208)

So, too, Weber painted a picture of massive historical and cultural shifts. His opus featured the iron cage of bureaucratic rationality, and stimulated creative responses to the quandary of whether and how it could be unlocked. Interested in myriad cultures, Weber would want to know, "How, do you Ali Mazrui, in your role as a leading African social scientist, go about painting an alternative canvas? What is your framework that springs from African soil?" In this vein, one might note that the title of Mazrui's book On Heroes and Uhuru-Worship, according to the author, "advisedly . . . echoes Thomas Carlyle's famous glorification of the role of heroes and hero-worship in history" (1967b:19). Discussing Josiah Mwangi Kariuki's treatise "Mau Mau" Detainee (1963), Mazrui, again invoking Carlyle's On Heroes, Hero Worship and the Heroic in History [1840]), supports his argument on heroism as follows: "'Give me a leader!' - this had been the passionate central thesis of Carlyle's philosophy" and of the Kikuyu generations later (1967b:19). Yet Mazrui's interlocutor would elicit more about the use of the proviso "advisedly" in his own work. Not to put too fine a point on it, Mazrui needs to explain what he means.

Curious about civilizations beyond European borders, Weber would also interject: "I use authority types as a guide to selecting heroes. Ali Mazrui, what is your compass for identifying iconic figures?" Indeed, it could be argued that the African pantheon contains an assemblage of slain heroes: among them, Steve Biko, Amilcar Cabral, Chris Hani, Patrice Lumumba, Eduardo Mondlane, and Samora Machel (who died under suspicious circumstances). The scholar-activists on the list would include Ruth First. "And more generally, where are the voices of the women in your writings? How is patriarchy portrayed?" (a debate played out vehemently in Mazrui [1998a, 1998b]; see also Ogundipe-Leslie [1998]). "Are the marginalized given sufficient scope? The unsung heroes?" While not a feminist, Weber, the cultural theorist, plumbed multiple levels of social structure in his account of the rise of capitalism.

As mentioned, Weber linked social theory to a universalist understanding of responsibility. In The Protestant Ethic and the Spirit of Capitalism (1958), questions of ethics involved "the spirit of capitalism." These norms featured a growing competitive ethos, today a motor of change, including in the intellectual domain. Consider the contemporary marketplace of ideas. In our own universe of knowledge production, what are the responsibilities of professors in the face of ideational circulation surrounding competition wherein a hierarchical, managerialist spirit typifies universities and is a driver of the downloading of globalizing ideas? 


\section{Said and Mazrui}

Relishing spirited debates and fond of hectoring political authorities, Said chimed with these points about the responsibilities of academics and representations of the margins. Certainly, Said, a member of the Palestine National Council, the legislative body of the Palestine Liberation Organization, until he split with Yasser Arafat, gave voice to the anguish and aspirations of the fringes.

Said emphasized the importance of the role of the public intellectual. Nowadays, in fact, our institutions of higher education seem to be producing too few of them. On this count, Mazrui has taken center stage. Like Said, he delivered the Reith Lectures and has sought to decenter knowledge, though Mazrui's critics challenge the veracity of his claims. Mazrui has also made numerous media appearances, has engaged power holders in political discourse about democratic participation, and has taken risks. Moreover, his views have reached general audiences through his novel The Trial of Christopher Okigbo (1971) and his nine-hour BBC/Public Broadcasting System television documentary series The Africans: A Triple Heritage, which contends that the modern history of Africa is a convergence of indigenous, Islamic, and Western cultures. ${ }^{4}$ It triggered protests, including from one of its funders, the U.S. National Endowment for the Humanities under Lynne Cheney, on the ground that the presentation was "an anti-Western diatribe" and that it "lacked balance and objectivity" (Frank 1998:304).

Said would likely respond differently, and query Mazrui: "Whose voices do you represent?" Said might well sharpen his probe: "Do your representations incorporate the voices of the oppressed? Do you account for their everyday lives? Or have you bleached the grassroots?" The feminist scholar and activist Molara Ogundipe-Leslie goes further. She lambastes him for essentialism, reductionism, and intellectual gamesmanship (see Mazrui 1998b). As she frames it, Why are you entitled to affix "the tag 'an African perspective"" to your article (1998:251)? More broadly, postcolonial theory frames the ethical dilemma facing researchers irrespective of their national or regional origins: Who authorizes whom to represent others?

Picking up on this theme, Wole Soyinka (1991, 2000) and Archie Mafeje (1995a, 1995b, 1998) chastised Mazrui for his alleged misrepresentations of Africa. Passionate in their beliefs, our elders tossed civility to the winds. They quickly dispensed with scholarly protocol, as spelled out, for example, in the 1990 "Kampala Declaration on Intellectual Freedom and Social Responsibility" (my emphasis), which was adopted at a CODESRIA symposium in which Mazrui participated. Ethical standards of responsibility, especially to a younger generation looking up to their role models, were cast aside.

The ensuing Soyinka-Mazrui and Mafeje-Mazrui fights turned into slugfests among intellectual warriors. As the rounds heated up, Mazrui (1991, 1992, 1995b, 1995c, 2000, 2008a) assumed a role represented in his own writings: the warrior tradition in African politics (see Mazrui 1977). Mazrui's offensive against Soyinka and Mafeje was redolent of the foremost 
classical theorist of war, Carl von Clausewitz, known for his maxim that war and politics are inextricably interrelated (1968[1832]). Clausewitz provided a rudimentary sociology that began to treat warfare as a social institution. Mindful that patriots in the revolutionary French army believed that they were fighting for rights throughout Europe, he had great respect for the power of ideas. And in a twenty-first-century reformulation of the Clausewitzian dictum that war is politics by other means, Michel Foucault held that "politics is the continuation of war by other means." Political power, he wrote, relies on "a silent war . . . to reinscribe it in institutions, economic inequalities, language, and even the bodies of individuals" (2003:15,16). In other words, power is a warlike operation.

The power/conflict interplay is evocative of the Mazrui-Soyinka-Mafeje dynamics. Going all out, these heavyweights punched below the belt. For instance, Mazrui's rivals alleged that his writings and lectures are self-indulgent and that he cultivates a following, even intellectual heroism, a theme that we will revisit. In return, Mazrui unleashed a powerful counterattack. In intellectual combat, he parried deftly. Matched against Soyinka and Mafeje, Mazrui, like a world champ, showed an uncanny ability to "float like a butterfly, sting like a bee." Floored by these no-holds-barred bouts, and safely tucked in the audience, I mixed up my Alis-Mazrui and Muhammad. In an imaginary brawl between them, the wily professor might have even come to a draw with the poet-philosopher-boxer, who spoke out on matters of race, culture, Islam, war, peace, and tolerance. Professor Ali would not have backed down. Perhaps he would have said: "Muhammad, you traveled to Kinshasa for a rumble with George Foreman, and I challenge you to come to Mombasa to debate me." Many people there would have enthusiastically greeted the professional boxer, not only because he is held in high regard, but also because, in Swahili communities, the name Muhammad Ali is quite common.

Or am I now emulating the genre of Ali Mazrui, whose harsh detractors claim that he toys with words and spins spurious associations?

\section{Mkandawire and Mazrui}

Mazrui's fortitude is remarkable. Bear in mind that his career stretches from the early years of political independence in Africa to the present. Chronologically, he spans the three generations that Mkandawire (1995) depicted. Given Mazrui's verve, if not nerve, who knows? Perhaps the next generation, two, or three as well? He keeps sprinting toward a better intellectual future.

A former CODESRIA executive secretary, Mkandawire has made a major intellectual impact, one aspect of which is the emphasis on the need for rigor in African studies. His legacy at CODESRIA includes the creation of research networks, publications, forums, and institutes that emphasize methodology, some of them specifically for young laureates. Accordingly, one could conjure an exchange in which Mkandawire, an economist, queries 
Mazrui, the culturalist: "What are your methods? How do you carry out your research? Is it rigorous or patchy?" Indeed, Mafeje (1998) and other critics, like Ogundipe-Leslie (1998), have lampooned him for substituting vivid alliteration, rich metaphor, and specious correlations for methodological due diligence. The hecklers attempted to poke holes in his schema and maintained that it is hardly bullet proof.

While Mazrui is well-equipped to defend himself explicitly, he builds his arguments implicitly, through textual analysis. Edward Said, too, worked in this manner, albeit in the service of a different political project. Said's data are literary texts. Ideas are played off against one another.

Using mixed methods to supplement textual analysis, Mazrui enlists concrete institutionalism (on pan-Africanism [1967c, 1997, 2005]), comparative inquiry (with African and American political thought [1967a]), and autoethnography (regarding gender and the family [1986, 1998a, $1998 b, 2000]$ ). In a form of memory research employed by historians, some feminists, and critical legal scholars, he mines his autobiography for material, as illustrations of identity politics. In my reading, the point of it all is to provide entrée to civilizational analysis. Mazrui leads his audiences into the mindset of overlapping groupings, including Muslim and African diasporas, as they interact with others and are deeply affected by cultural flows across borders. Avoiding reductionism, he explores cultural complexity, exemplified by his own Arab and African heritage. Mazrui opens worldviews and institutions, such as his own extended family, to readers (see Institute of Global Cultural Studies 2006). But will this defense satisfy Mazrui's critics, who expect systematic information on, and explanations of, more than a one-time ruling family on the coast of East Africa? Far from being anecdotal and quixotic, as his adversaries contend, his work presents the microcosm as a way to see the big picture. Mazrui uses analogical reasoning as a heuristic for connecting concrete phenomena.

Still, what about the subaltern's lived experience? Is the civilizational talk among intellectuals elitist? Does it engage the discourses of East Africa's wananchi (citizens), in the sense of ordinary people? Are the academics actually listening to them? When I put my ear to the ground in the region's villages and poverty-stricken urban areas, the people's wants are expressed in terms of chakula (food), maji (water), kazi (work), afya (health), elimu (education), and the like.

If I may again assume his own inimitable style, Mazrui is a great conceptualizer but not a great particularizer of empirical evidence. To be sure, he digs empirically. But the excavations are not as empirically thoroughgoing as some observers demand. Methodologically, the litmus is no less than the meticulous production of knowledge.

Like Weber, Mazrui is a methodological individualist. But Weber was more reflective on questions of method and epistemology (1949). He developed a methodology-ideal types-as a way to gather troves of data on history and culture. While Mazrui also brings out the cultural accoutrements of politics and social structure, he is the more eclectic workman. 
And like Mkandawire, whose job portfolio includes a stint as director of the United Nations Research Institute for Social Development, Mazrui is an institution builder. Both Mkandawire's and Mazrui's professional service encompasses the goal of buttressing and shaping the knowledge structure in African studies. Mazrui has advised international agencies such as, inter alia, the United Nations Children's Fund and the World Bank; participated on the editorial boards of several journals; held posts as a university administrator, such as chancellor of Jomo Kenyatta University of Agriculture and Technology (Nairobi); and been active in professional associations, including as president of the U.S.-based African Studies Association.

Whereas Mkandawire traced three generations of African intellectuals, a fourth generation is rising. The future is upon us. Writing in 1995, Mkandawire looked ahead to the issue of regeneration of knowledge. Surely his insight about generational differences is astute, especially given all the attention he devotes to other axes of stratification: gender, race, ethnicity, class, religious groupings, and so on. But does Mazrui endorse Mkandawire's characterization of generational diversity at African universities? And are Mkandawire's observations in need of updating? To what extent have value systems changed? Does Mazrui find that Mkandawire's 1995 projection stands the test of time? Does it hold up to closer scrutiny of today's multigenerational institutions in Africa? And what is Mazrui's vision for the successor generations? In what kind of environment can they best act as responsible knowledge generators?

For Mkandawire, greater intellectual autonomy is warranted. To bolster research in Africa, the intelligentsia needs its own space for debate and creativity as well as unfettered academic freedom. Universities must be sanctuaries for critical reflection, though not disembedded from societal conditions. In his plethora of publications and lectures on this very theme, Mazrui endorses this general view. But exactly what picture of universities does Mazrui draw? Beyond bemoaning the constraints on African universities, he proposes an ecumenical tack for resuscitating them. It involves redialing into, not disconnecting from, global perspectives. In a chapter published in a book on rethinking the possibilities for African intellectuals edited by Mkandawire (Mazrui 2005), and in other venues, Mazrui fleshes out several strategies.

Counseling parametric change, Mazrui (1995a) prescribes indigenization, but not cultural autarky. According to him, delinking would only continue marginalization. Rather, decolonizing the university requires broader diversification of its content: enabling local societies to have broader influence on the curriculum, altering the criteria for recruitment of faculty so as to embrace traditional skills, and revising the adoption of Western disciplines whereby holistic concerns, such as rural development, become schools in their own right. Paradoxically, more Africanization entails more internationalization and multiculturalism. This is a matter of modifying language requirements and emphasizing knowledge of regions such as Asia and Latin America. Building on emerging market power, there is an opportunity for 
enhanced South-South initiatives to "counterpenetrate" Western educational systems. But for real reciprocity, African universities should build capacity for creativity and innovation.

Mazrui has extended these ideas for transforming universities to incorporate the pursuit of "ecology-friendly production and consumption in Africa," which would guard against the deleterious effects of industrialization (2008b:3). A main goal is mobilizing resources: in other words, developing relations with the state and private donors. Specific ways to move ahead have been mapped out, especially in addresses presented by Mazrui (2003, 2011) in his role as university chancellor in Kenya. These notions are bound to be contested. But entertaining controversy is his forte.

\section{Punch Line}

The preceding discussion adopts a joyful mode of celebrating Ali Mazrui's many achievements. At root, however, it is not intellectual play. This article affords an occasion to pose serious challenges. Perhaps Mazrui will want to respond and make clear the analytical framework undergirding his output. The responses could help further African studies.

In the foregoing dialogues, the inquisitors have raised a host of questions. To wrap up, the following queries center on grappling with the drivers of social transformation and, in a dynamic global milieu, what makes Africa tick. The interlocutors want Ali Mazrui to step up to their charges about how to theorize African conditions.

In closing, let us pick up on four aspects of this exchange of ideas:

First, do you emphasize agency at the expense of deep structural forces? If not, how do they operate? What are the underlying structures? Ideas? Material power? And how to join such factors?

Second, should the agents be construed as atomized individuals with ample freedom of maneuver? Or are social individuals tethered to resilient structures, as both Weber and Marx believed, even though, in their prefigurations of globalizing forces, these theorists differed on the engines of change?

Third, in view of persistent constraints, is the scope for political leaders narrowing? Do methodological individualists grant too much autonomy to them?

Fourth, how then can we expand policy space so as to build ladders of development? How to advance in the hierarchy of the global division of labor and power? For the welter of stakeholders in Africa, what are the alternatives?

Getting high marks on this assignment is a tall order. Likely, as proven over several decades, Mazrui will excel in advancing the realization of a better intellectual community. It is safe to bet that he will continue to contribute powerfully to winning a just future. Yet there is no telling what surprises Mazrui has in store for us. You can rest assured that he will not pull any punches. 


\section{Acknowledgments}

This is a revised version of a paper presented to a roundtable titled "The Legacy of 'Pax-Africana': In Honor of Professor Ali A. Mazrui” at the annual conference of the African Studies Association, Washington, D.C., November 17-20, 2011. I owe a debt of gratitude to Seifudein Adem, associate director of the Institute of Global Cultural Studies (IGCS) at Binghamton University, for kindly sharing research material. Thanks, too, to Linda Yarr and the African Studies Review's anonymous reviewers and editors for comments on a draft of this article.

\section{References}

Clausewitz, Carl von. 1968 [1832]. On War. Translated by J. J. Graham. Edited by Anatol Rapoport. London: Penguin.

Diouf, Mamadou, and Mahmood Mamdani, eds. 1994. Academic Freedom and Democratic Struggle. Dakar: CODESRIA.

Foucault, Michel. 2003. "Society Must Be Defended": Lectures at the Collège de France, 1975-1976. Translated by David Macey. New York: Picador.

Frank, Diana. 1998. "Producing Ali Mazrui's TV Series The Africans: A Triple Heritage." In The Global African: A Portrait of Ali A. Mazrui, edited by Omari H. Kokole, 297-307. Trenton, N.J.: Africa World Press.

Gramsci, Antonio. 1971. Selections from the Prison Notebooks. Translated and edited by Quintin Hoare and Geoffrey Nowell Smith. London: Lawrence and Wishart.

Harris, Marvin. 2001 [1968]. The Rise of Anthropological Theory. London: AltaMira Press.

Institute of Global Cultural Studies Staff. 2006. "From Zanzibar to Harlem: The Mazrui Family as a Case Study." Binghamton, N.Y.: Binghamton University.

Jung, Dietrich. 2003. "A Political Economy of Intra-State War: Confronting a Paradox." In Shadow Globalization, Ethnic Conflicts and New Wars: A Political Economy of Intra-State War, edited by Dietrich Jung, 9-26. New York: Routledge.

Kampala Declaration on Intellectual Freedom and Social Responsibility." 1990. http:/ / abahlali.org; republished 1994 in Academic Freedom and Democratic Struggle, edited by Mamadou Diouf and Mahmood Mamdani, 349-53. Dakar: CODESRIA.

Kariuki, Josiah Mwangi. 1963. "Mau Mau” Detainee. London: Oxford University Press.

Kokole, Omari H., ed. 1998. The Global African: A Portrait of Ali A. Mazrui. Trenton, N.J.: Africa World Press.

Mafeje, Archie. 1995a. "Benign" Recolonization and Malignant Minds in the Service of Imperialism." CODESRIA Bulletin 2: 17-21.

- 1995b. "'Recolonisation' or 'Self-Colonisation' in Pursuit of 'Pax Africana': Another Response to a Reactionary Thesis.” CODESRIA Bulletin 3: 16-19.

—. 1998. "The Beast and the Icon: No End to Ali Mazrui's Pax Africana Muddles." CODESRIA Bulletin 2: 9-11.

Mazrui, Alamin M., and Willy M. Mutunga, eds. 2003. Debating the African Condition: Mazrui and His Critics. Volume 2: Governance and Leadership. Trenton, N.J.: Africa World Press.

- 2004. Debating the African Condition: Mazrui and His Critics. Volume 1: Race, Gender and Culture Conflict. Trenton, N.J.: Africa World Press. 
Mazrui, Ali A. 1967a. Ancient Greece in African Political Thought. Nairobi: East African Publishing House.

- 1967b. On Heroes and Uhuru-Worship: Essays on Independent Africa. London: Longmans, Green and Co.

- 1967c. Towards a Pax Africana: A Study of Ideology and Ambition. London: Weidenfeld and Nicolson.

- 1971. The Trial of Christopher Okigbo. London: Heinemann.

- 1977. The Warrior Tradition in Modern Africa. Leiden: Brill.

- 1986. The Africans: A Triple Heritage. New York: Little Brown.

1990. Cultural Forces in World Politics. London: James Currey.
1991. "Wole Soyinka as a Television Critic: A Parable of Deception." Transition

54: 165-77.

—. 1992. "The Dual Memory: Genetic and Factual.” Transition 57: 134-46.

- 1994. "The Impact of Global Changes on Academic Freedom in Africa:

A Preliminary Assessment.” In Academic Freedom and Democratic Struggle, edited by Mamadou Diouf and Mahmood Mamdani, 118-40. Dakar: CODESRIA.

_ 1995a. "The 'Other' as the 'Self' under Cultural Dependency: The Impact of the Postcolonial University.” In Encountering the Other(s): Studies in Literature, History, and Culture, edited by Gisela Brinker-Gabler, 333-62. Binghamton, N.Y.: State University of New York Press.

—. 1995b. "Pax Africana: Between the State and the Intellectuals." CODESRIA Bulletin 3: 19-22.

- 1995c. "Self-Colonization and the Search for a Pax Africana: A Rejoinder." CODESRIA Bulletin 3/4: 20-22.

—. 1997. "Africa's Own Trusteeship System: Pax Africana Has Begun.” CODESRIA Bulletin 3: 14-16.

- 1998a. "The Black Woman and the Problem of Gender: An African Perspective." In The Global African: A Portrait of Ali A. Mazrui, edited by Omari H. Kokole, 225-47. Trenton, N.J.: Africa World Press.

—. 1998b. "Woman as Victim, Woman as Victor." In The Global African: A Portrait of Ali A. Mazrui, edited by Omari H. Kokole, 259-65. Trenton, N.J.: Africa World Press.

- 2000. "Dr. Jekyll and Mr. Soyinka: The Strange Case of Nobel Schizophrenia."

- 2002. Africa and Other Civilizations: Conquest and Counter-conquest. Volume 2: Collected Essays of Ali A. Mazrui, edited by Ricardo René Laremont and Fouad Kalouche. Trenton, N.J.: Africa World Press.

—. 2003. "In Pursuit of Excellence: Towards Rehabilitating Kenya's Universities." Chancellor's inaugural address, Jomo Kenyatta University of Agriculture and Technology, November 8.

—. 2005. "Pan-Africanism and the Intellectuals: Rise, Decline, and Revival." In African Intellectuals: Rethinking Politics, Language, Gender and Development, edited by Thandika Mkandawire, 56-77. Dakar: CODESRIA Books.

- 2008a. "Debating Archie Mafeje and Wole Soyinka: Can Africa Colonize Itself?" CODESRIA Bulletin 3/4: 10-11.

_. 2008b. "Higher Education and the Seven Pillars of the African Renaissance." Presentation at Columbia University Teachers College, New York, March 17.

- 2011. "Africa between the Baobab Tree and the Owl of Minerva: A PostColonial Educational Narrative.” Paper presented at the annual conference of the Comparative and International Education Society, Montreal, April 30-March 4. 
Mazrui, Ali A., Patrick M. Dikirr, and Shalahudin Kafrawi, eds. 2008. Globalization and Civilization: Are They in Conflict? New York: Global Scholarly Publications.

Mittelman, James H. 1997. "Academic Freedom, Transformation, and Reconciliation." Issue 25 (1): 45-49.

- 2010. Hyperconflict: Globalization and Insecurity. Stanford, Calif.: Stanford University Press.

Mkandawire, Thandika. 1995. "The Challenge of the Third Generation of African Academics?" CODESRIA Bulletin 3: 8-12.

- 2010. "Running While Others Walk: Knowledge and the Challenge of Africa's Development." London School of Economics and Political Science Inaugural Lecture, Chair of African Development, April 27.

Morewedge, Parviz, ed. 2001. The Scholar between Thought and Experience: A Biographical Festschrift in Honor of Ali A. Mazrui. Binghamton, N.Y.: Institute of Global Cultural Studies, University of Binghamton.

Mwangola, Mshaï S. 2008. "Nurturing the Fourth Generation: Defining the Historical Mission for Our Generation.” Africa Development 33 (1): 7-24.

Ngũgĩ wa, Thiong'o. 1986. Decolonising the Mind: The Politics of Language in African Literature. London: James Currey.

Ogundipe-Leslie, Molara. 1998. "Beyond Hearsay and Academic Journalism: The Black Woman and Ali Mazrui." In The Global African: A Portrait of Ali A. Mazrui, edited by Omari H. Kokole, 249-58. Trenton, N.J.: Africa World Press.

p'Bitek, Okot. 1966. Song of Lawino: A Lament. Nairobi: East African Publishing House. Said, Edward W. 1994. Representations of the Intellectual. New York: Pantheon Books.

Schmitt, Carl. 2003[1950]. The Nomos of the Earth in the International Law of the Jus Publicium Europaeum. Translated and annotated by G. L. Ulmen. New York: Telos Press.

Soyinka, Wole. 1991. "Triple Tropes of Trickery." Transition 54: 120-27.

—. 2000. "The Problem with You, Ali Mazrui! Response to Ali's Millennial 'Conclusion." West Africa Review 1 (2). www.africaknowledgeproject.org.

Weber, Max. 1973[1946]. From Max Weber: Essays in Sociology. Translated and edited by Hans H. Gerth and C. Wright Mills. New York: Oxford University Press.

- 1949. The Methodology of the Social Sciences. Edited and translated by Edward A. Shils and Henry A. Finch. New York: Free Press.

. 1958. The Protestant Ethic and the Spirit of Capitalism. Translated by Talcott Parsons. New York: Charles Scribner's Sons.

\section{Notes}

1. Passages below on Gramsci and Weber echo my August 14, 1996, speech delivered as the Richard Feetham Memorial Lecture on Academic Freedom in Africa (Mittelman 1997), the lecture series at the University of the Witwatersrand, Johannesburg, that was launched in 1959, when Chancellor Richard Feetham and many of his colleagues refused the government's order, under the Separate University Education Bill, to segregate the university. (Previously, Wits and the University of Cape Town were "open universities," and admitted students without regard to race or color.) When the bill became a law, thousands of students and staff marched through the streets protesting the state's attempt to enforce apartheid in the universities. For further analysis of academic freedom in Africa, see Diouf and Mamdani (1994), and Mazrui's chapter in the same volume. 
2. It would be remiss to fail to draw attention to a cornerstone of this thinking. Apposite to comprehending the exile condition is the notion of nomos, which for the German philosopher and legal scholar Carl Schmitt ([1950] 2003), as discussed in Mittelman (2010), encapsulates the constitutive processes of order and orientation. Orders are world historical events that may be distinguished from one another, and manifest a political and juridical rule. They also instill orientation, which springs from the local, the earth in a spatial sense (as in an attachment to the land), and thus below the heights of the economy and the state. So, too, nomos entails enclosure: erecting fences, drawing borderlines, and forming identities. In other words, nomos expresses orders that unite as well as divide. Inasmuch as history remains open and fluid, a new nomos may emerge. Tacit categories of superordinate and subordinate groups are formed anew. They include the Other among people who live amid one another. In this process, the constructs of homeland and internal and external exile are defined or self-defined, as in Germany during the Nazi period, when Schmitt, an ardent anti-Semite, aligned with the National Socialist party and provided intellectual rationale for the "fatherland."

3. Mwangola (2008) addresses these issues from the standpoint of a member of the emerging fourth generation.

4. See Mazrui's book (1986), which bears the same title. 